\title{
To Study Relationships Between Men and It's Environments by Enlivening Bedouins Heritage in Modern Dubai
}

\author{
Marian Ahmed and DN Ayesha Mushtaq* \\ Dietitians, Allama Iqbal Open University, Pakistan
}

Submission: October 20, 2019; Published: November 06, 2019

*Corresponding author: DN Ayesha Mushtaq, Dietitians, Allama Iqbal Open University, Islamabad, Pakistan

\begin{abstract}
Region and culture have been influenced in shaping the past architecture space. It is to examine that vernacular architecture in the modem cities of the United Arab Emirates (UAE). And how this view creates obstacles in the interaction of satisfying historic building forms and techniques. The greatest obstacle is the complex symbolic role that these buildings play in modem nation building. The objective of this study is to analysis the interaction between Tradition and Modernity in contemporary architecture and its relationship to the vernacular and cultural aspects, as evident in the case of the United Arab Emirates. While historic buildings are viewed with homesickness, they are also not deemed suitable for contemporary life and have been isolated in the process of economic and social development, separated from enlivening social activities, historic architecture in the UAE seems designed to survive only as outdoor museum displays.
\end{abstract}

Keywords: Temperature; Water; Ordinary recourses; Environment; Human beings; Lifestyle; Tea; Drink; Mutton; Coffee; Cultivate crops; Goats; Sheep; Camels

\section{Introduction}

From the beginning human being were just travelers changing from one place to another. According to the temperature, water, and ordinary recourses. They settled in a place which is more comfortable for them. Human beings gather around to makeliving. And that way of living identified their culture. Every nation has a distinctive culture. Human living started from our first parent (Hawa and eve) who came to their Earth then they made living out of Natural Material which were available at their time. This shows that human beings adapt their environment according to their progress, movements, death, and decay etc. Thus, all living including man and their environment are mutually responsive to each other in many ways. Human beings (society) and the environment are dependent. If the natural environment helped in the development of different structures of the society, on the one hand, the existence and quality of environment now rest on the responses of these social structures to the environment on the other hand. Human life is directly and indirectly affected by climatic conditions. The vernacular architecture utilizes these conditions in order to provide dwellers with the comfort they seek. Vernacular building is a building built by local people using traditional technologies from locally available materials matching the environmental context to accommodate domestic ways of life it is a description that is completely in accordance with what is known today as sustainability. Everything that human does is a response to the environment. The shape of the land affected where human moved. The weather was something with which to contend Because of the weather human being started to spend most of the times indoor [1].

Bedouins are animal herders who migrate into the desert during the rainy winter season and move back toward the cultivated land in the dry summer months. Bedouin tribes have traditionally been classified according to the animal species that are the basis of their livelihood. Camel nomads occupy huge territories and are organized into large tribes in the Sahara, Syrian, and Arabian deserts. Sheep and goat nomads have smaller ranges, staying mainly near the cultivated regions of Jordan, Syria, and Iraq. Cattle nomads are found chiefly in South Arabia and in Sudan, where they are called Baqarah (Baggara). Historically many Bedouin groups also raided trade caravans and villages at the margins of settled areas or extracted payments from settled areas in return for protection. Bedouins are people who have historically inhabited the desert regions in North Africa, the Arabian Peninsula, and the Levants (Figure 1). 


\section{Current Research in Diabetes \& Obesity Journal}

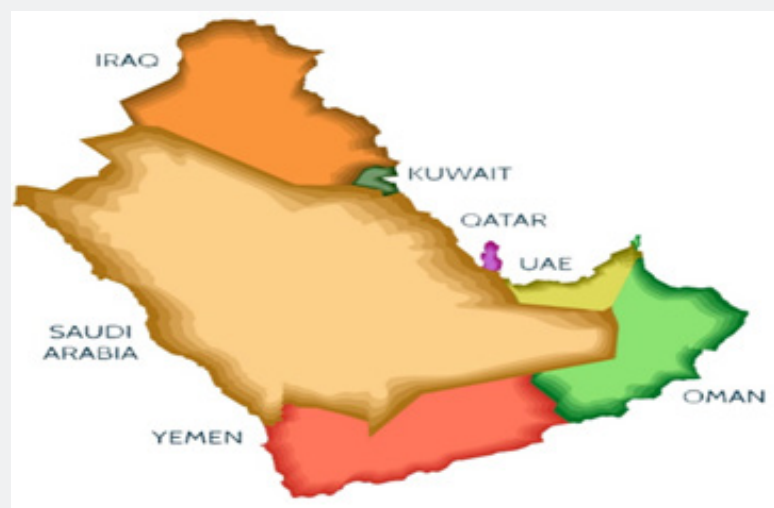

Figure 1: Arabian Peninsula.

\section{Desert and Sand-Desert of Arabia}

In Arabia there are many desert areas suited to the life of the Bedouins. As already mentioned above, one tends first to think of such lands in terms of sand-deserts. The largest of these is the Rub 'al-Khali (the empty quarter), the famous sand-desert in southern Arabia extending from Oman in the east to the Yemeni frontier in the west and to Najd in the north. Its area is about twice that of all of France and many regions of it remain unknown, despite the writing about it by western explorers, most notably Bertram Thomas, ST. John Philby, and Wilfred the siger. To the north it merges into the second sand-desert, the Dhana'. Which lies to the west of the Asha region, runs parallel to it and to the and to the Arabian Gulf, and connects the Rub al- Khali to the sand-desert of the Nafud. The third is the sanddesert of the Nafud, which covers the norther Hijaz as far as the Gulf of al - Aqaba. According to some estimate, there is enough sand in these deserts in Saudi Arabia alone to encircle the entire world with a belt of sand nine meters wide and one meter deep. There is also the sand-desert of Sinai, to the north and west of alAqaba, and finally the northern sand-desert of Sinai, to the north and west of al-Aqaba, and finally the northern sand-desert, the major part of which is called the Syrian Desert, or Badiyat alsham. Although it does contain broad expanses of sand here and there, the Syrian desert is not a sand-desert comparable to the other four. Indeed, in many parts of it there is good soil, where many more kinds of herbage will grow than in the other sanddeserts, making it a paradise for the Bedouin seeking a place to stop and graze his animals. The Syrian desert spreads itself out in the form of a great triangle. One base angle lies above the Iraqi city of al-Basra on the Arabian Gulf, and is connected to the other, above the gulf of al-Aqaba on the Red Sea, by an imaginary line cutting across Iraq, the kingdom of Saudi Arabia, and the Hashemite kingdom of Jordan (Figure 2).

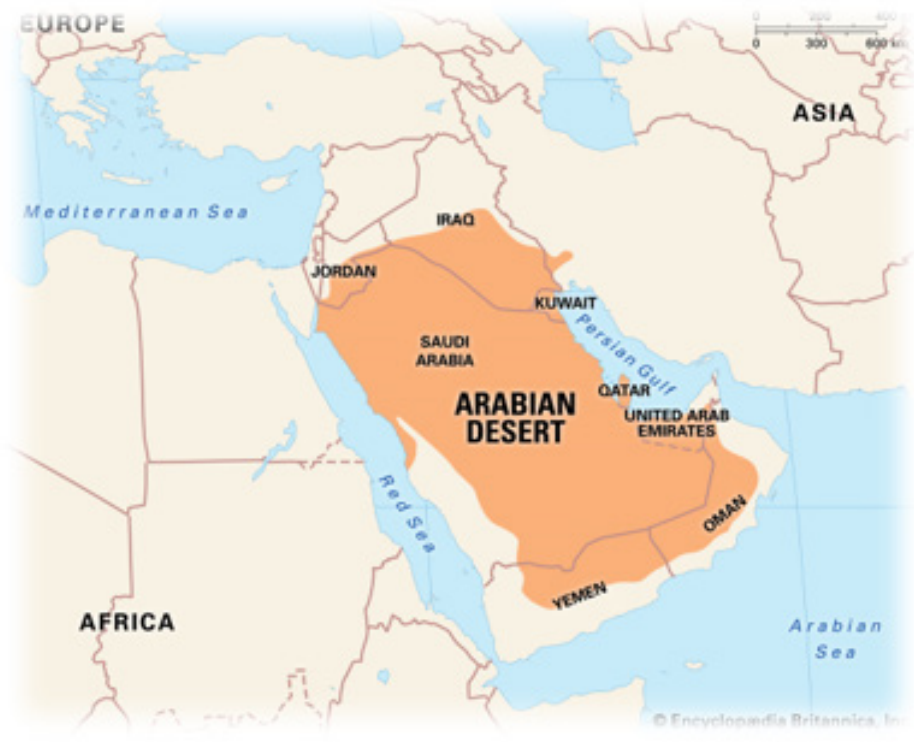

Figure 1: Arabian Peninsula 


\section{Current Research in Diabetes \& Obesity Journal}

The third great angle (in the shape of an arch) lies west of Tadmur in Syria and near the peripheries of the Euphrates in the jazira. As already suggested, this desert should more properly be called by this name in order to distinguish it from the sand -desert mentioned above. Traditional Arab usage divides the northern desert into three desert zones: the Syria desert in southern Syria, the jazira desert adjoining turkey in Northern Syria, and the Iraqi Desert in southern and western Iraq. In these three deserts there is little rain, the annual average not exceeding a few centimeters. It is more plentiful in the north than in the south, and usually occurs only in the winter, though some rain may occasionally fall in the autumn or early spring. Southeasterly or northwesterly winds are conducive to rainfall; but when the wind shifts to the north, the clouds disperse and rain ceases [2].

\section{Bedouins Lifestyle and their Tents}

Traditionally, the Bedouin's home, the tent, is divided into three sections by curtains: the men's section, the family section and the kitchen. In the men's area, guests are received around the hearth where the host prepares coffee on the fire. This is the center of Bedouin social life. Tea is served as a welcome drink; coffee is usually prepared after the meal and is the last drink before the guest leaves. The serving of food and drink represents the generous hospitality of the host. The men pass the evening trading news and discussing their animals. Separated from them by a curtain, the women gather in the family area and kitchen along with their small children to bake bread and prepare the main meal. A dinner of rice and chunks of mutton or lamb are then served to the gathered guests (Figure 3 ).

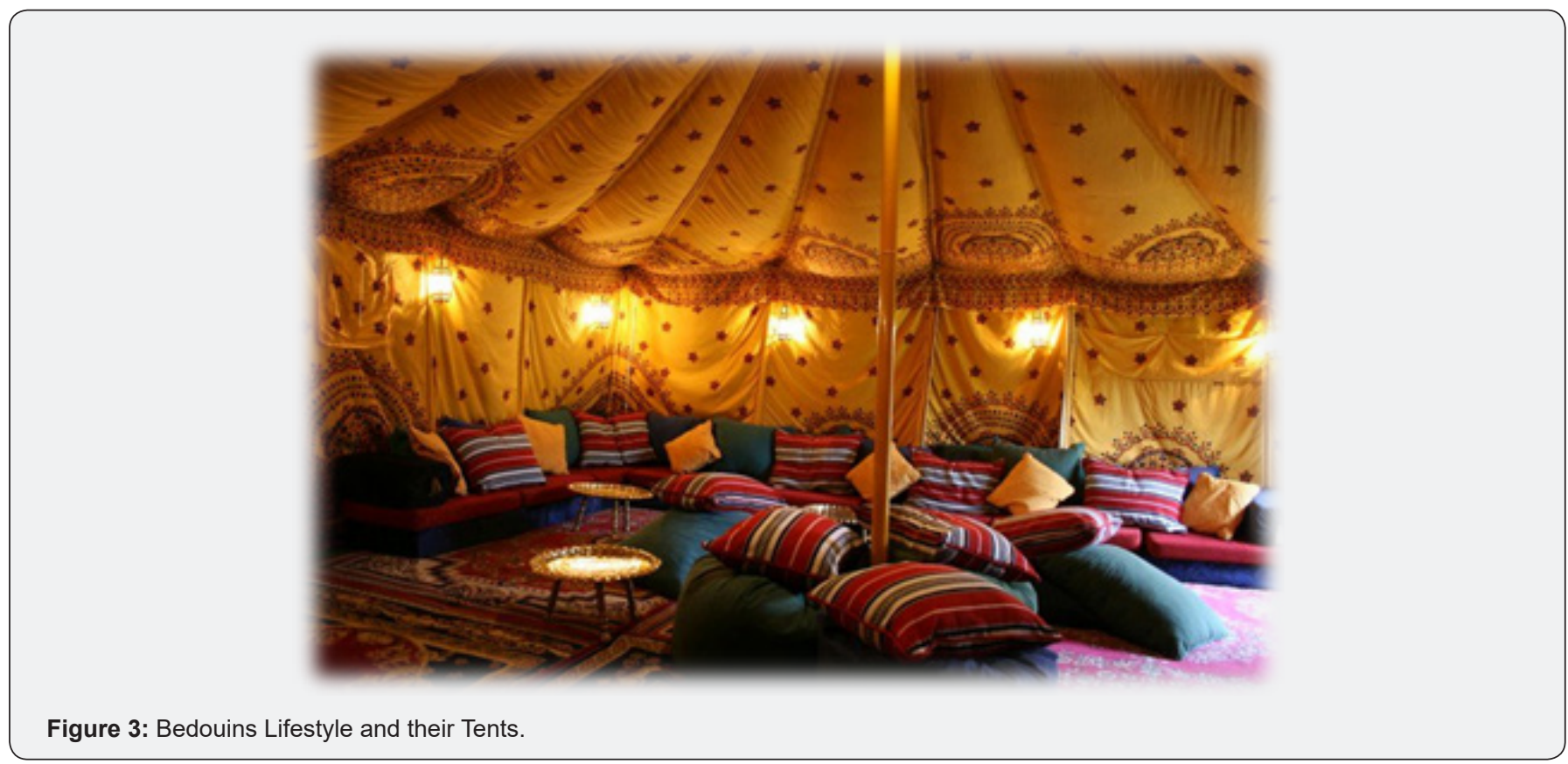

This is the center of Bedouin social life. Tea is served as a welcome drink; coffee is usually prepared after the meal and is the last drink before the guest leaves. The serving of food and drink represents the generous hospitality of the host. The men pass the evening trading news and discussing their animals. Separated from them by a curtain, the women gather in the family area and kitchen along with their small children to bake bread and prepare the main meal. A dinner of rice and chunks of mutton or lamb are then served to the gathered guests. Women occupy a very important position in Bedouin society. Not only do they raise the children, herd the sheep, milk the animals, cook, spin yarn and make the clothes, but they also weave the cloth that constitutes the tent. The Bedouin men gather around the fire, sharing stories and sipping coffee. Traditionally, one of the men recites poetry or sings. To mark the end of the evening, the host burns incense in a makhaira (incense burner) passing it to each of his guests to inhale and fan their clothes. Poetry has been a central cultural form of expression for the Bedouins throughout their history. In early centuries of Islamic history, Bedouin poetry represented the ideal standard for other literary achievements, as well as for the Arabic language. The traditional foods of the Bedouin are dairy products and meat. Bedouins sell and barter products in order to obtain agricultural food from sedentary peoples (Figure 4). Bedouins are often stereotyped as constantly wandering the desert in search of water and food for their flocks. This state of constant wondering is called "Terhaal". Only a small portion of Bedouin can still be regarded as true nomads, while many have settled down to cultivate crops rather than drive their animals across the desert. Most Bedouin have combined the two lifestyles to some degree. Those Bedouins who still practice pastoralism will camp in one spot for a few months at a time, grazing their herds of goats, sheep or camels 
until the fodder found in the area is exhausted. Bedouins are most famous for their hospitality, and it is part of their creedrooted in the harshness of desert life-that no traveler is turned away. The tribal structure of Arab society is also most visible among the Bedouins, where the clan is at the center of social life. Each Bedouin family has its own tent, a collection (hayy) of which constitutes a clan (qawm). A number of these clans make up a tribe, or qabila. They are continued to be hailed by other Arabs as 'ideal' Arabs because of their rich oral poetic tradition, their lifestyle and their code of honor. Bedouin are distinct from other Arab's because of their extensive kinship networks (which provide them with community support and the basic needs to survive) and their rich culture. These networks are traditionally to ensure safety of families and to protect their property [3].

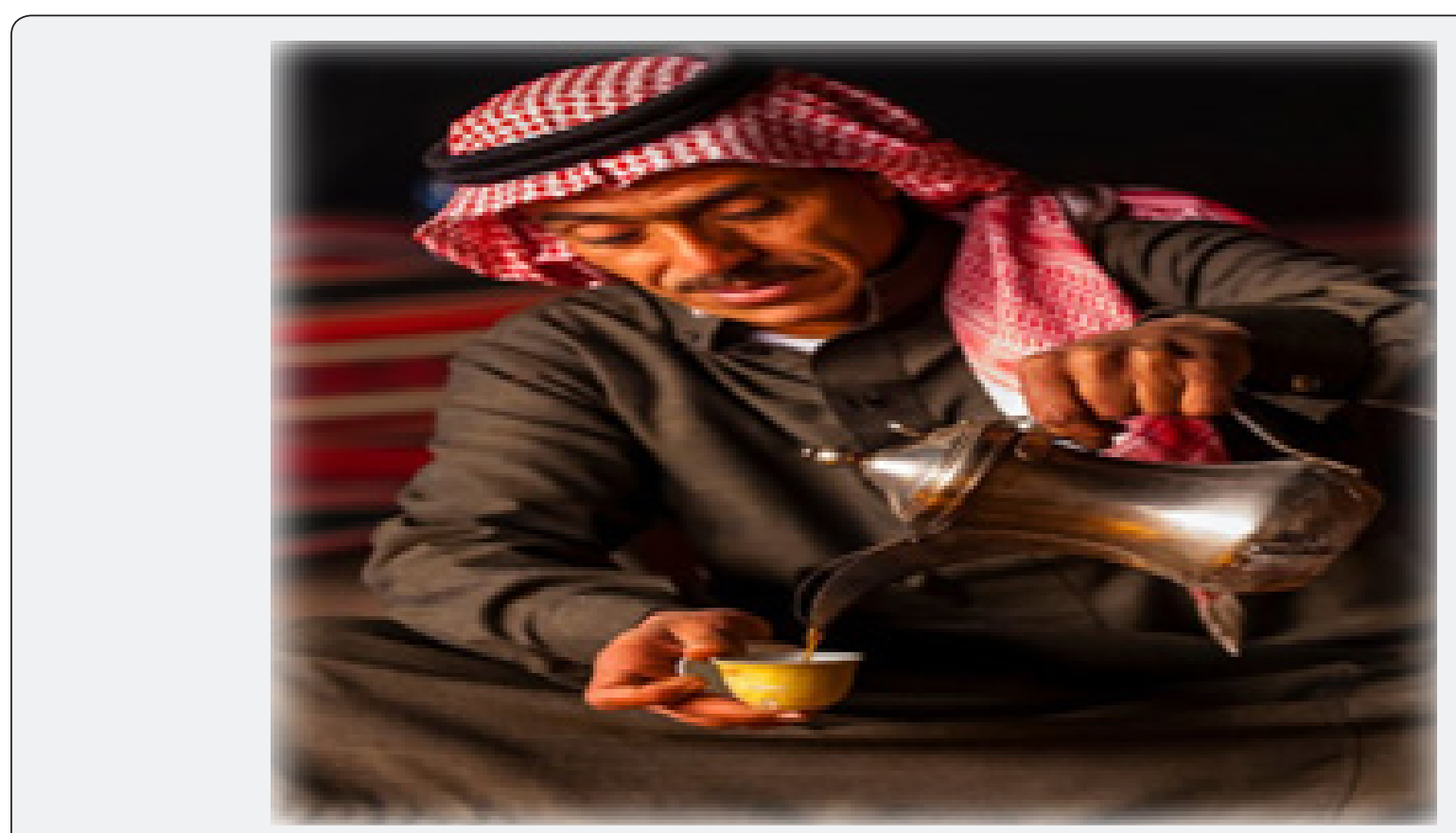

Figure 4: Bedouins Lifestyle.

\section{The Falcon}

Just as the lion is the noblest and strongest of the predatory mammals, the falcon is regarded as the strongest and noblest of birds. As the poet Iliya Abu Madi said on this subject. "If you would be wild, then fierce lion be; or flying on wing, a falcon let's see."

In praise of the falcon they used to say: "The best of images is that combining three features a falcon on the hand of a man on the back of a horse. Boasting of himself, the Umayyad poet 'Umar ibn Abi Rabi speaks of a visit to one of his female companions: Naught will surprise them like those cream-colored camels, with riders and packs as they came up the hill, and a horseman with falcon whom they pointed out to her with compliments fine, saying, "look, if you will."

The Bedouins purchase falcons from village folk in the settled lands adjoining the desert in Syria, Najd, the Hijaz, and Kuwait, as do amirs and shaykhs in most of the Arab emirates. The series of falcons are to be found in rocky heights and mountain, where you can see experts in such matters searching the rocky mountain tops until they find their way to the bird's nest or climbing a cliff where they see a falcon's aerie so they can collect its chicks while they are small. There are usually three chicks per nest, and these the collectors take before they leave the nest to fly (Figure 5). The falcon can catch most kinds of birds, such as the pigeon, partridge, francolin sand grouse, and others like them; but the largest bird it can kill is the bustard. It can also catch all kinds of rabbits and some Bedouins even go so far as to claim that the falcon hunts the gazelle. In fact, it does sometimes help in gazelle hunting if trained to do so. When the hunter sees the salukis chasing a gazelle, he sends up the falcon, which flies over the gazelles, swoops down on its head as it runs before the dogs, and obstructs it's vision by flying in front of it. Or it may land on the gazelle's head and strike it with its beak, thereby impeding its progress so that the dogs can catch up to it and kill it. Just as al-Farazdaq wished that he were together with his beloved, his drinking cup, and a falcon to catch a bustard so the two of them could eat piece of its meat, so the Rwayli poet wished that he had a falcon and a hunting dog to turn loose to hunt as he stood near some beautiful girls about to break camp: "Would that a hound and a bird were mine, and saddle cinched on a young camel fine. Twixt guard and tribe would fall our pace, to call the hound while bird does chase" [4]. 


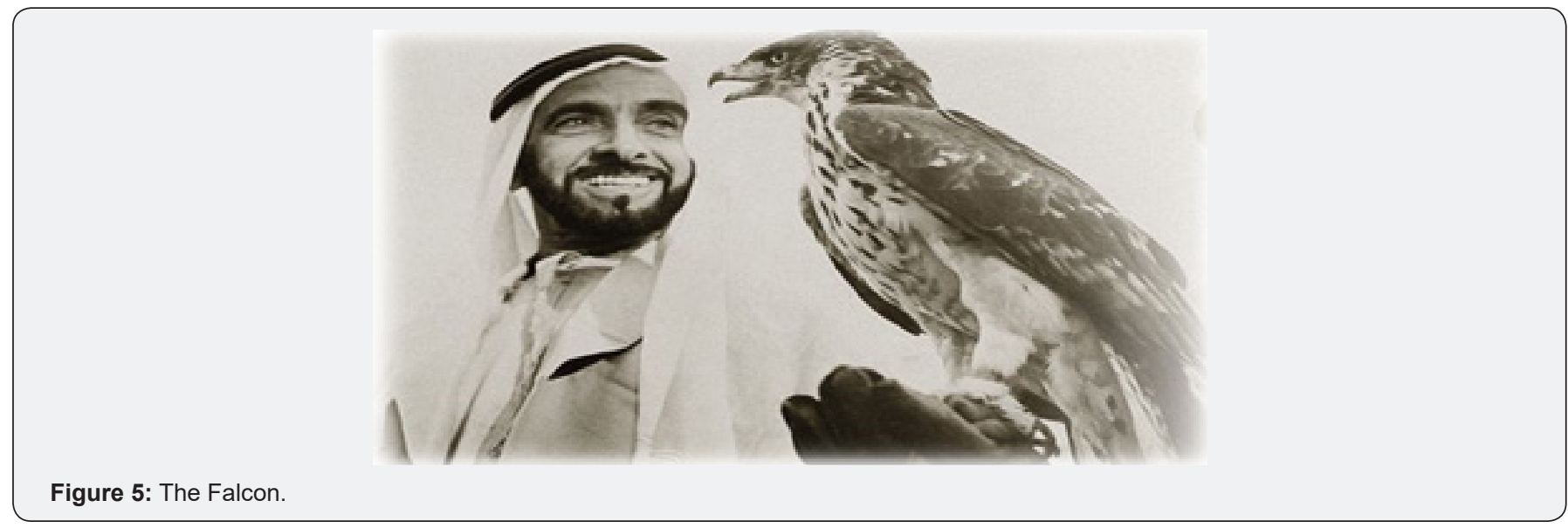

\section{The Horse}

The horse is great influence in the life of the Arabs in general and the Bedouins in particular and played a significant role in the military successes achieved by the Arabs in their long history. Arabian horses have been renowned throughout the world since remote antiquity. Horse breeders in many areas outside the Arab world have begun to import and breed Arabians, and have striven to mix the strains of their horses with Arabian blood; as a the result, one now only rarely finds beautiful thoroughbred horses whose blood lines are not mixed with those of the Arabian. There is no image that reflects the Arab sense of pride as beautifully as does the image of an Arab on a thoroughbred horse. Indeed, the word furusiya ("horsemanship") in the Arabic language, and its connotations of gallantry, nobility, might, and fortitude, are derived from terms for the mare (faras) and the horseman (faris), and the word faris has also come to mean "hero." As their port said: If hero you'd be, then be like Ali; Or if poet you'd be, then be like Ibn Hani (Figure 6).

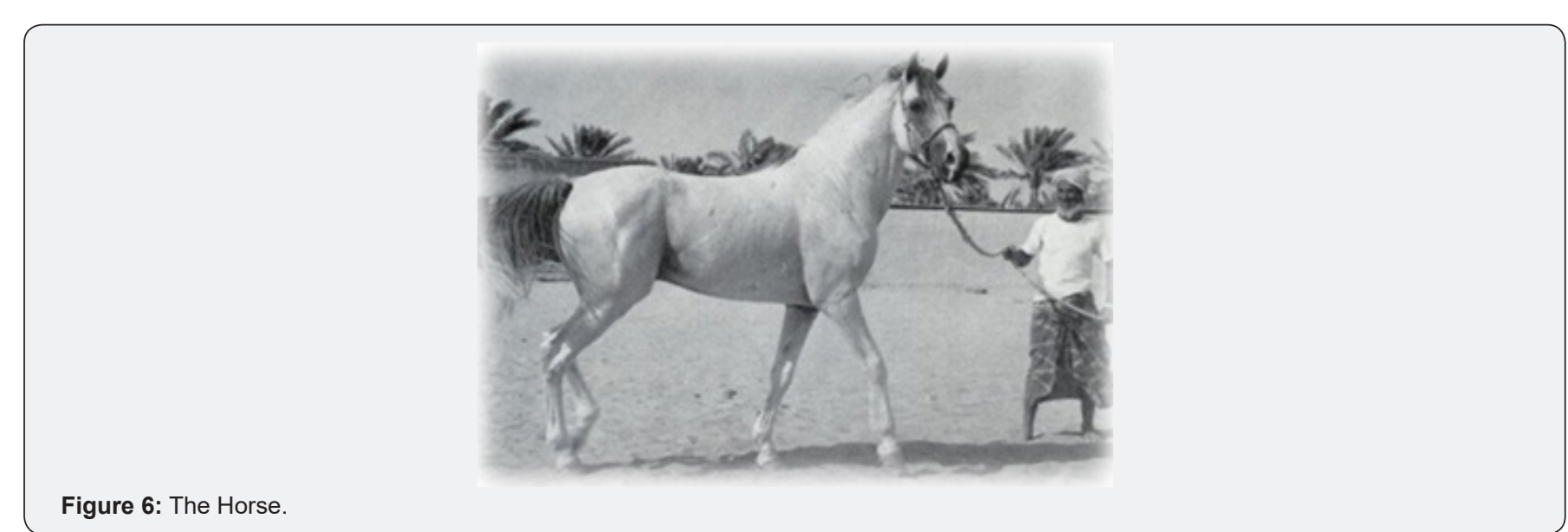

\section{Objectives}

a) To create outdoor environment which will interact between human beings.

b) To connect human beings with nature and its environment.

c) To make society healthy in all perspectives.

d) To eliminate isolated environment and create friendly environment.

\section{Scope}

There is no scope of vernacular architecture in middle east. As they are trading in modern architecture. But the root and historical of middle East is all about vernacular architecture so they preserved their old buildings to keep their culture more appealing to the world. But since contemporary design are in demand their cultural building is hidden with tall building. So, to revive their culture it's necessary redesign the interior of the museum. The concept of the vernacular as a progenitor of urban and architectural ideas has been a subject of debate over three decades. To look for urban or architectural ideas based on the actual arrangement of spaces and buildings of a locality or a region, increasingly becomes an answer. In a sense, the vernacular combines the best of both worlds: it is both conservative and radical, pragmatically based in experience while also being a source for new urban and architectural solutions. Urban planners, urban designers and architects turn 


\section{Current Research in Diabetes \& Obesity Journal}

to the vernacular to reestablish contact with the fundamental nature of arrangements of spaces and building, and to recreate a basic urban and architectural form. It is a return to the roots, or fundamentals. The vernacular represents a truth of fundamentals and is more at home with the landscape. (Eben Saleh, n.d.) Middle east is trading center and people visit around the world for business. Other then business it's a land which is architecturally beautiful. People also come for tourism. Its country rich of oil, camels and dates. The lack of moisture in the air means that there's a lot less mold in the desert. The lack of rain also means that many more opportunities to go outside and hike. Exercise is one of the best ways to keep stress low. The significant of this place is that people visit from different countries. So, it's important to show the culture and preserve their heritage in old building Dubai Museum [5].

\section{Rationale}

My aim is to connect tourist and local people with the rich culture of middle East. And to reviving their culture inside old building Dubai museum. So, Individual spend most of their days in the museum, and to know history of middle east desert and Bedouins. It will be a place where people will interact and explore real culture and heritage of United state of emirates UAE. The interior of the structure will be traditional. And the material will be of dessert nature. Finally, I offer some observations on what might be done to encourage the appreciation of historic buildings and the expanded role they might play in contemporary life.

\section{Strategic Plan}

In-order to design anything, whether according to a specific set of rules or not, a plan needs to be devised which will ensure throughout the whole process that everything is being carried out accordingly. In this thesis, the plan devised was simple yet carefully strategized. To ensure effective design, the location was first surveyed, and current design was noted. Then the neighboring locations were identified and their purpose as well as adjacency to the building was noted for future reference. It was decided that by doing this, not only would it benefit the users of that location but would do for the surrounding locations too.

\section{The Dessert Homeland}

\section{Defining and describing the desert}

A place said, to be like a sahra is expensive and a people are said to be folk of the Sahara when they go out to Avast open space where there is nothing to conceal them from view. A land called a sahra is generally level terrain, which both smooth and rugged places, but no prominent hills. When the people go out from the settled areas to the grazing ground of the Santa land, they are called Bedouins (badw). It is obvious from this that there is no great difference between the two terms. Indeed, some of the dictionaries draw no distinction at all between them; in such works we find that "the badiya is the sahra and the sahra is the badiya. Today the dessert are a focus of world attention because of their resources, primarily oil and petroleum by products, and because of their vast extend, which according to some scholarly estimates comes to a total of approximately eight million square miles, or about one seventh of the land surface of the earth [6].

\section{Site analysis}

Site location: The physical area of Al- Fahadi Historical District is located at Al-Hamriyah bur Dubai. It is the area of traditional style building in typical materials housing arts and cultural Exhibits and museums. The location is important to consider because it effects the building and the environments. They are I have selected is very old and historical building of dubai. All the neighboring building which are very old is restored with dubai culture and heritage. It is a tangible entity and work influence on the area through several factors.

Terrain: The physical topography of the land help us to understand the horizontal and vertical dimensions of the land. The land can be of Alluvial plain, soil plain, rugged desert, sandy plain or any other plain. Topography help us to understand the land surface and it dimensions. The natural geography of the area was an estuary (a landform consisting of a penetration of the sea in the coast) or creek, which, despite its shallow depth, offered natural conditions for development of a port. Dubai Creek was extended in the 50s to facilitate the port's functions. This creek divided the original city into two parts: Deira and Bur Dubai northeast to southwest (Figure 7).
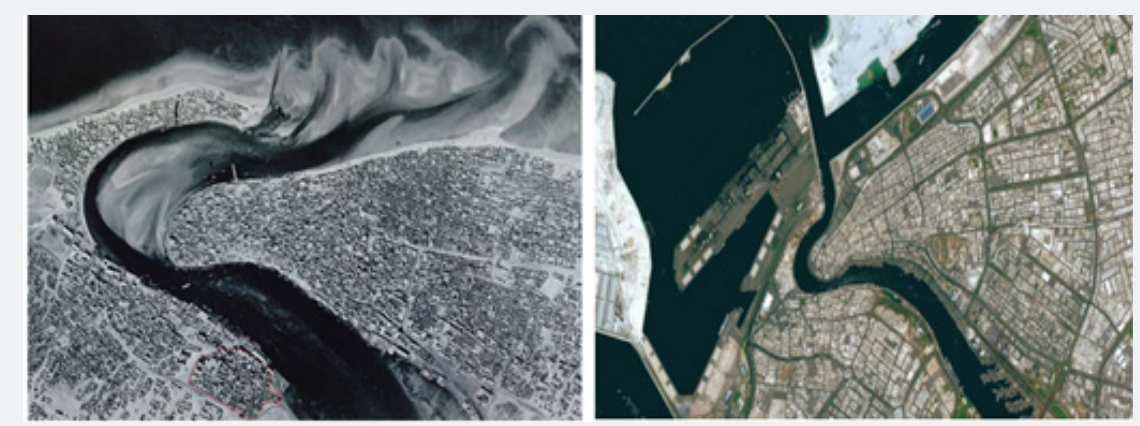

Figure 7: a) Before 20 Century

b) After 20 Century 
Climate: The temperature of any area plays important role in affecting the building directly. So before selecting a site we have to consider every climate factor. Middle East is very dry and hot land. Due to the harsh weather the nomads used to travel from one place to another by means of their camels. It is arid steppe region land. The amount of yearly rainfall is very rare may be once in the whole year. The soil red lines show maximum temperature of average day for every month. And the soil blue line shows the average minimum temperature of average day for every month. Dash red and dash blue line indicate average of the hottest days and coldest nights of each month for the whole year. Bedouins migrated into this desert during the rainy season and move back towards cultivated land in the city of summer months. The desert climate is harsh during the day, hot and dry, the relative humidity sometimes dropping as low as about seven percent. The level the rises during the night, and water vapor condenses as drops of dew that after dawn one can see soaking the ground and revitalizing the herbage. In spring, some women go out to place thick with herbage and collect the dew in their waterskin; and livestock that graze on such herbage may sometimes go, if only for a short while, without finding water, as we shall see when we take up the subject of desert animals and birds (Figure 8). The desert heat is intense, in the summer sometimes rising to more then $50^{\circ} \mathrm{C}$. in the shade, and at night falling to about $20^{\circ} \mathrm{C}$. the combination of dry climate with the extremes and erratic fluctuations in temperature during the summer permits only certain special kinds of tree and plants to live in the desert. These are thorny or thorn- like types (if I may be permitted this term), the leave of which do not have large surface area through which water would evaporate during the intense heat of spring and summer. Animal must be of those particular species that can live from these plants, both green and dry, and that can go without water for a longer period of time than other animals can endure. The desert environment may be harsh and life in it miserable, but its climate is generally salubrious. As am Maqrizi reports: Umar ibn al khattab related that he asked ka'b al Ahbar about the natural characteristics of the lands and the innate dispositions of those who lived in them. Ka's replied: "when Almighty God created things, he made for each of them a partner. Intellect said, 'I am setting out for Syria;' and Discord said, 'And I go with you.' Hardship said, 'I am setting out for desert;' and salubrity Said, 'And I go with you.'

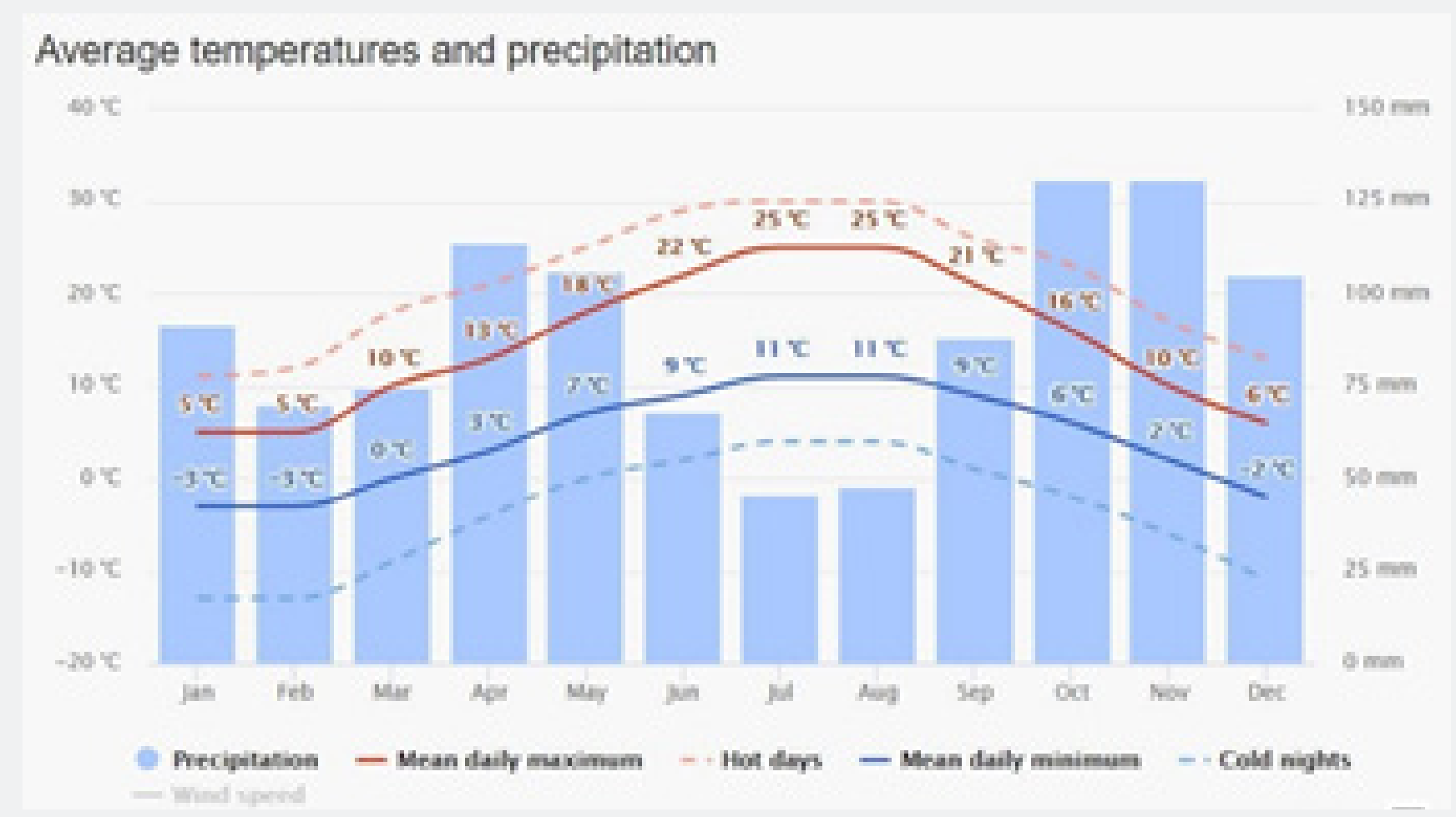

Figure 8: Average Temperature and Precipitation.

\section{Wind towers}

In later technology the badious build the building using wind tower which is also called (barajils). Wind tower is built in square shape and is located at the social area of the building. From above I we can understand the working of wind tower. In blue color indicates the breeze air from outside is going inside the home, it ventilates the house even with the doors closed. And the green color, the air is sucked and taken out of the house. Before the concept of widow, majority nomads used the technique of wind tower so that the air enter from all sides of the house and ventilation will be maximum (Figure 9). 


\section{Current Research in Diabetes \& Obesity Journal}
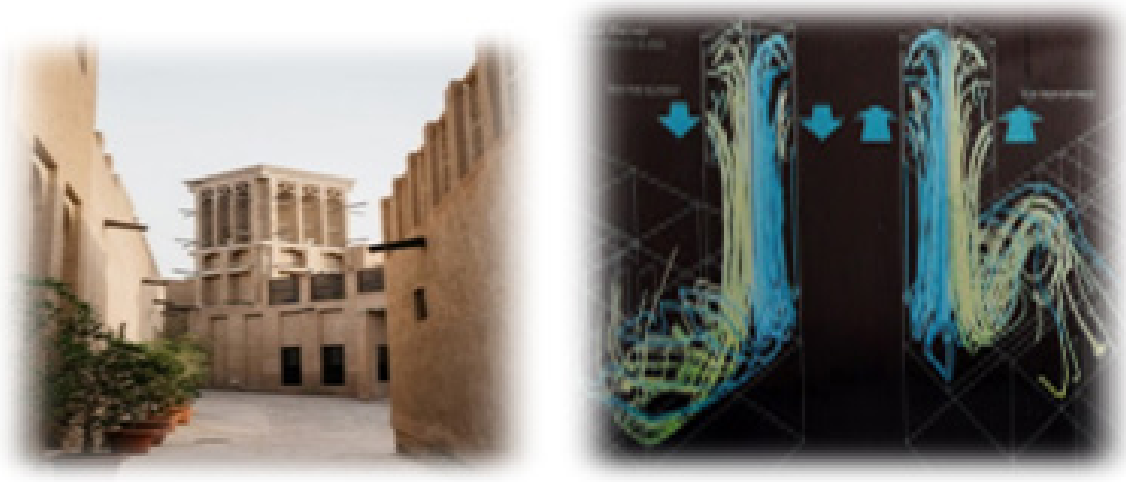

Prevailing Wind

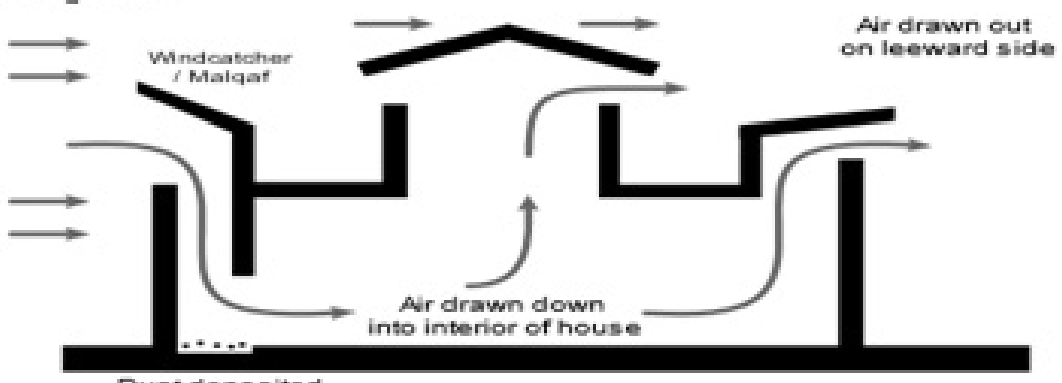

Dust deposited

Figure 9: Wind Towers.

Access points: The roads, streets or path which lead to the space, the way the space is approached has huge impact on itself.

Neighborhood: The physical context of space, is surrounded by heritage and cultural buildings. Unfortunately, the building is now lost in between modern building of Dubai. Al Fahidi Historical Neighborhood identified as most visited place in
Dubai by lot of cultural explorers \& tourists. Al fahidi is located in cultural and heritage district. Following is the neighborhood of Al- Fahadi Historical building. XVA gallery, Majlis Alareesh, Wall of old Dubai, Drawing and engraving, Coin museum bur Dubai, Architectural heritage society, Emirates philatelic association, Arabian tea house restaurants and café, Sheikh Mohammad center for cultural understanding (Figure 10).

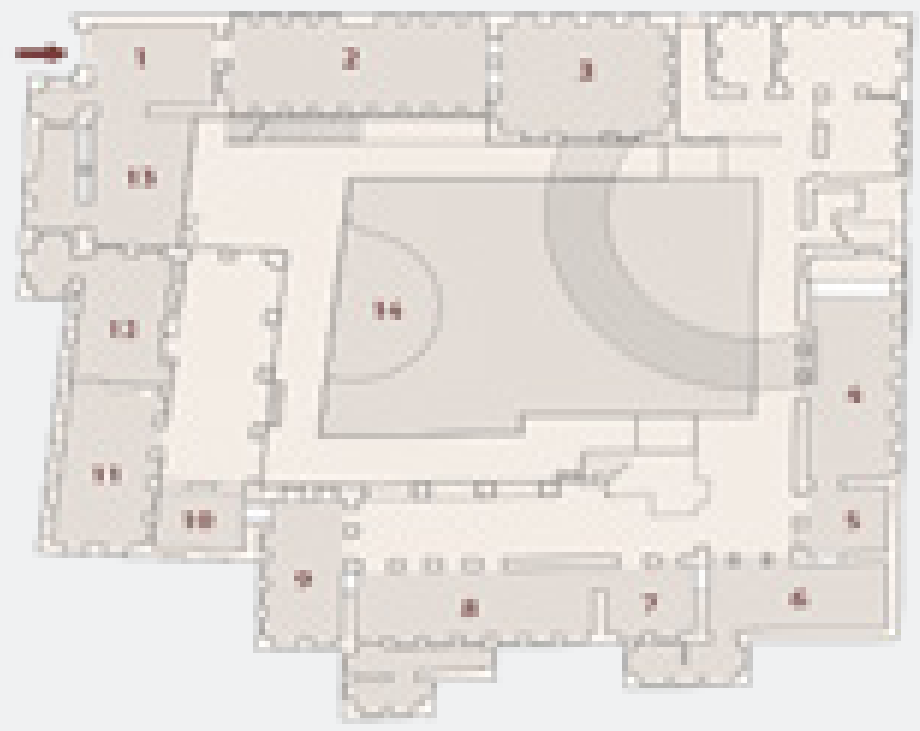

Figure 10: Wall of Old Dubai 


\section{Current Research in Diabetes \& Obesity Journal}

History: The reason why the space exists at the first place, and why it was reserved till now? Is something worth considering. The building Al Fahidi Historical District (Bastakiya) is located at but Dubai. And it was build constructed by Muhammad shareef Al olama (1930-1931). The building surface area is about 663 square meters. It is of two-story building and it's linked by three stone staircases around central closed yard. Al bastakiya is a very rich in its architecture structures such as wind tower (barajeel), columns, arches, their capital and wooden ornaments. Al basatakiya is surrounded by other heritage buildings (Figure 11).

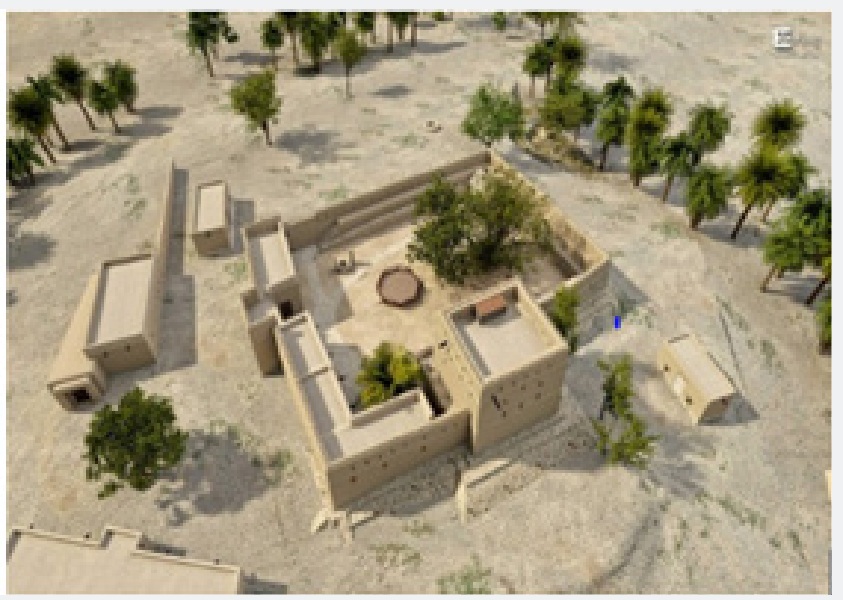

Figure 11: Al Bastakiya.

Stakeholders: The class and type of people that live there and the bond between them. Bedouin used to live in this dry land. Bedouin are people who lived with animals' herders. Animal (camels) are their transportation mean and are basis of their livelihood. Pedestrians of that area used to build their house through vernacular architecture. their level of interaction with the environment and communities surrounding them all come under this factor of analysis.

Tangibles: The tangible entities serve as solid masses defining each point of an urban space. Dubai museum is surrounded by other historical building mentioned above. This historical site is cultural district and is located in old side of Dubai. The building is well maintained, and tours and local people visit this museum.

Functionality: The specific purposes and functions of this building is visit and see the historical cultural and heritage of the building. Majority people visit to the museum is the local people. Tourist also visit this place but not often.

\section{President Study}

Louvre Abu Dubai Museum is located at saadiyat island. The Louvre Abu Dhabi is an art and civilization museum, located in Abu Dhabi, UAE. The museum was established on 8 November 2017. It is part of a thirty-year agreement between the city of Abu Dhabi and the French government. The museum is located on the Saadiyat Island Cultural District. It is approximately 24,000 square meters $(260,000 \mathrm{sq}$. $\mathrm{ft})$ in size, with 8,000 square meters $(86,000 \mathrm{sq} . \mathrm{ft})$ of galleries, making it the largest art museum in the Arabian Peninsula. Louvre Abu Dubai museum was completed in eight years (2009-2017). The architect of louvre any Dubai is Jean Nouvel (France architect) the idea of this building was to create a bridge museum of Africa, Asia, middle east, and Europe. France paid €399 million for thirty-year use and loaned three-hundred artworks from thirteen different museum in France. And the museum collected two hundred pieces thirty-five artwork from its own collections. This museum was built and balanced on the water front of saadiyat island, half a kilometer off the coastal mainland (Figure 12).

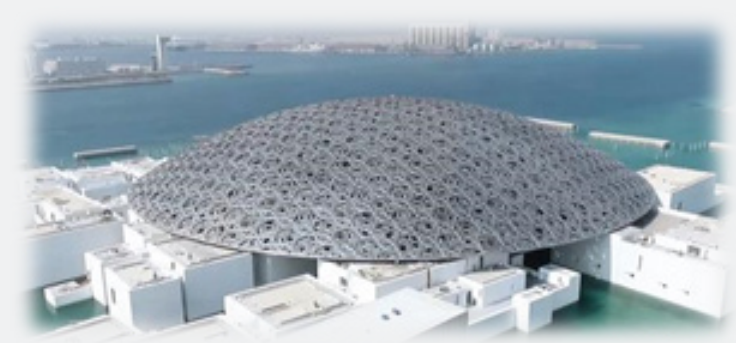

Figure 12: Louvre Abu Dubai Museum. 


\section{Current Research in Diabetes \& Obesity Journal}

\section{Site Location}

Louvre is located in the old city of Dubai; main road is sheikh Khalifa road in Zayed. The location of louvre museum is surrounded by historical and district. Neighborhood building are:

Aptitude café, Minaret al-Sadat, Saadia civil defense.

Born out of an intergovernmental agreement signed on March 6, 2007, between the United Arab Emirates and France, the Louvre Abu Dhabi is the first universal museum in the Arab world. The museum brings the Louvre name to Abu Dhabi and presents both ancient and contemporary works of historic, cultural, and sociological interest from around the world [7].

\section{Design Concept}

Louvre Abu Dubai museum was built with concept of Middle East small culture. The idea was to connect fifty-five blocks and each block represented different tasks. Nouvel sought to create a "neighborhood of Art", as he scattered of fifty-five white blocks, the louvre Abu Dubai is spread-eagled out as if it were a village on a water, complete with a maze of intersecting passages. Louvre Abu Dubai museum has twelve Gallery showcase, sixhundred twenty artwork. Painting, Neo-classical sculpture, and contemporary installation arranged chronologically from prehistory to the present. This museum is also called "humanity in New light" and louvre museum represent the culture of middle east and it is the Anti-thesis of Burj- Arab (Figure 13).

Figure 13: Design Concept.

\section{Creating A Rain of Light}

To give the interior the impact of "Rain of light" was far from easy. The steel dome structure was inspired from Eiffel tower in Paris, France which was built on 1791, it was public space meant for everyone. The idea was to "bring together monuments to all the sciences and Arts". Engineer Bur happold, designed the steel done structure and the vast done has span of five-ninety feet and one-thousand eight hundred fifty feet circumference. Most extreme climates, and it's spectacular done plays an important role in the museum's Environment strategy. It acts as a shading canopy to protect the outdoor plaza and the building below from the suns intense heat. Clustered under the Dome, fifty-five individual building make up the museum city. 600,000 sq. Feet around 58,000 sq. Feet of art and exhibition spaces are arranged in a group of simple geometric forms haphazardly arranged in reference to traditional city. These galleries have to adhere to strict international standard protecting artwork. To regulate the amount of daylight entering the galleries every window and roof light has three blinds. Two diffusers and a blackout blind. These operates automatically depending on the time of the day. The time of year and how much daylight is present with its impressive art, architecture and engineering, the louvre's dessert outpost it set to become a key landmark in Abu Dubai (Figure 14).

Figure 14: Creating A Rain of Light. 


\section{Current Research in Diabetes \& Obesity Journal}

\section{Steel Dome Structure}

The Dome is perforated to create an internal effect. The Dome is an extremely complex structure constructed of more than 400,000 individual elements weighting 12,000 tones almost as much as Eiffel tower. The dome's structure is a steel space frame that rests on just four support. "This micro-city requires a microclimate that would give the visitor a feeling of entering a different world. The building is covered with a large dome, a form common to all civilizations. The dome is made of a web of different patterns interlaced into a translucent ceiling, which lets a diffuse, magical light come through in the best tradition of great Arabian architecture. Water is given a crucial role, both in reflecting every part of the building and acting as a psyche, and in creating, with a little help from the wind, a comfortable microclimate." Each pattern is different than the other. First layer is pattern is wider than its top patter the design gets Complicated from bottom to top this way it will create opening each opening space will have different patterns. After many try and performance this steel dome was constructed in is perfect shape. The dome's steel structure core is covered with eight perforated layer of cladding four on top and four underneath [8].

\section{Construction of the dome}

To construct the Dome, eighty-five super-sized steel elements, each weighting between 50 and 70 tones, were craned into place, supported by nearly 120 temporary towers. These elements were joined together with steel connectors once complete; the whole dome was lifted off the temporary tower and lowered 15 inches down onto the four permanent piers. The result of years of testing, including a full-size mockup placed on site carefully calibrated to modulate the light and temperature conditions of the internal space. Holding it together is a mosque like dome, (or church) resplendent with silver lattice work futuristic almost rising above a bed of gentle, ripping seawater that fills the outer corridors. The depth of the building is 24,000 sq. Foot under the water and to make the building foundation is stronger. The material used in the exterior of the wall is white tile.

\section{Interior of louvre}

The sculpture shines in the last room of louvre Abu Dubai. But the sculpture has history dating back to 1919 when

\section{Earth Architecture for Poor}

louvre Abu Dubai opened last November, Ai Weiwei's dazzling fountain of light, a twisting steel containing 32,400 glass crystal, quickly became a social media star. Placed in the gallery of the permanent collection, the sculpture caps the journey through the museum. Above it a panel has been removed in the ceiling, as if the structure itself winds outwards the story done above the reflection of the glass pendants danced on the surface, an aqueous element that appeared in its title, working progress (fountain of light).

\section{Conclusions}

Designing a museum must relate of the culture of that particular area. The architect Jean novel studied the history and culture of Arab and designed according to their culture. So now this museum speaks out more about Arab culture. The museum has strong meaning and it's previous to Arabs. "A museum," said Novel, as we wove our way through alleyways and courtyards, past reflective canals of water that lend a Venetian air, "should be part of the town and of life."

\section{Precedent study}

Fathy devoted himself to housing the poor in developing nations and deserves study by anyone involved in rural improvement. Fathy worked to create an indigenous environment atand in and in doing so to improve the economy and the standard of living in rural areas. He integrated his knowledge of the rural Egyptian economic situation with a wide knowledge of ancient architectural and town design techniques. He trained local inhabitants to make their own materials and build their own buildings.Climatic conditions, public health considerations and ancient craft skills also affected his design decisions [9].

\section{Design concept}

"No other project dominates this mature phase of the architect's work as much as the village of New Baris, in a way that is comparable to the notoriety of New Gourna twenty years before. There are so many contrasting factors between the two projects that it is beneficial to examine the parallels between them. Discovery of a large water well sixty kilometers south of the Kharga Oasis in 1963, which had been estimated to have the capacity to continuously irrigate up to 1000 acres of land, led the Organization for Desert Development to propose an agricultural community here at that time.

Figure 15: Hassan Fathy.

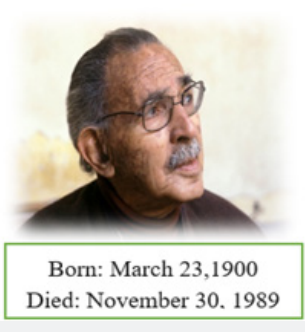




\section{Current Research in Diabetes \& Obesity Journal}

Hassan Fathy was a noted Egyptian architect who pioneered appropriate technology for building in Egypt, especially by working to reestablish the use of adobe and traditional as opposed to western building designs and lay-outs. Fathy was recognized with the Aga Khan Chairman's Award for Architecture in 1980. In 2017, Google celebrated Fathy with a Google Doodle for "pioneering new methods [in architecture], respecting tradition, and valuing all walks of life" (Figure 15).

As he himself describes it: "Baris was an interesting problem in which I was to create all the parts of a community, to bring together in the best manner possible people whom I did not know. All that I had at my disposal were demographic, geographic and climatic surveys. I had to provide the aesthetics, the sense of man in a space constructed by man".

Fathy concentrated on a thorough study of both the traditional architecture and climate of the region. In addition to examining the fourth century AD mudbrick ruins of the necropolis of Bagawat nearby, he also closely observed the existing village of Kharga, where the material used, as well as the width and orientation of the streets and introverted forms of the houses effectively offset summer temperatures as high as 50C degrees that could potentially cause serious physiological problems for the people living there. New Gourna was a housing project masterminded by Hassan Fathy with the objective of rehousing the Seven Thousand people of Gourna, a village built on the site of the Tomb of the Nobles, part of the ancient cemetery of Thebes (now Luxor, Egypt). The project incorporated traditional techniques and materials and vernacular styles with the benefit of contemporary know-how, generating an economically and ecologically sustainable building ethos that was integral to the community that would occupy the village.

\section{Stake holders}

The class and type of people that live there and the bond between them. Bedouin used to live in this dry land. Bedouin are people who lived with animals' herders. Animal (camels) are their transportation mean and are basis of their livelihood. Pedestrians of that area used to build their house through vernacular architecture. their level of interaction with the environment and communities surrounding them all come under this factor of analysis.

\section{User analysis and research}

Q. when you are traveling, how do you pick a museum to visit? (Figure 16).

Figure 16:

Q. Does the museum interior experience take you to the lifestyle of Arabs (Bedouins)? (Figure 17).

Figure 17 


\section{Current Research in Diabetes \& Obesity Journal}

Q. After you have visited a museum and had favorable experience, is your response mostly based on? (Figure 18).

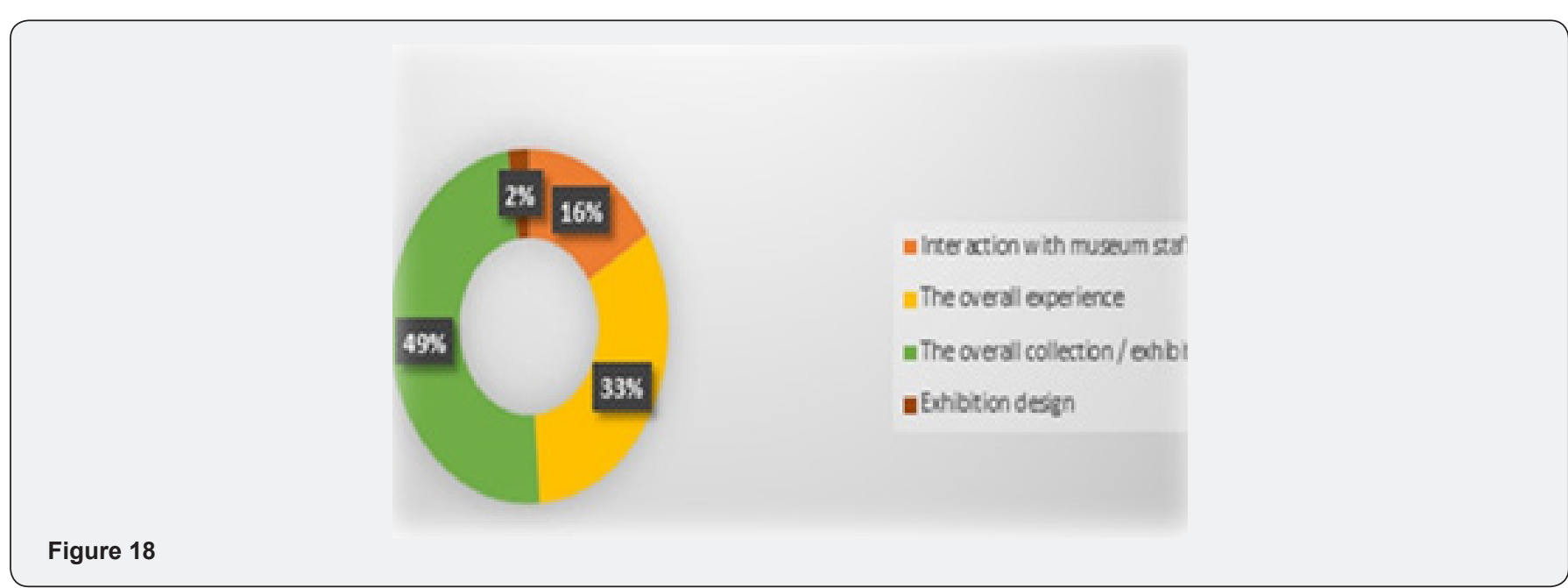

Q. Does one part of a museum experience have more importance to you than another? (Figure 19).

Figure 19

\section{Conclusion}

From all this analysis i have learn how human can have impact on the building. Need and requirement of people should be considered it throughout the design.

\section{Design Concept}

\section{Design brief}

The thesis paper focuses on badious lifestyle and their vernacular architecture. badious living style and the way the create their spaces speaks out for middle east culture. Although the country old heritage culture is covered with modern architecture building people still visit and explore the real culture of middle east. My aim is to design museum interior which will give more meaning to the culture of Arabian peninsulas.

\section{A chronology key of middle east}

The city was first mention in book of geography An Ancient book dating back to the year 1095. In earlier times, it was part of byzantine Empire's pre-historical communities, which were eventually conquered by Umayyad caliph group

1833 - The Maktoum clan, which is part of the Bani yas tribe, takes over the small fishing settlement of Dubai

1892 - The pearling industry flourishes in Dubai. Foreign traders arrive, doubling the population.

1912 - The school, Al Ahmadiyya school was built. Today it has been restored historical site in old Dubai.

1930 - The recession hits the pearl industry, resulting into tension and conflict among ruling families in Dubai and nearby area

1958 - Sheikh Rashid become the ruler of Dubai after the death of his father

1966 - Oil is discovered in Dubai, attracting foreign traders and enhancing economic growth 
1971 - Dubai join other Emirates to form the United Arab Emirates (U.A.E)

1973 - The dirhams (AED) Become the official unit of currency in Dubai

1985 - Dubai's flagship carrier, Emirates is established, and the city begins to transform into a tourist destination.

1990 - Sheikh Maktoum becomes the ruler of Dubai, after the death of his father, sheikh Rashid.

2003 - Dubai is recognized by the world bank and international monetary fund as a financial Hub

2006 - Sheikh Mohammad becomes the prime minister and vice president of the UA, and ruler of Dubai.

2010 - The tallest building in the world, burn khalif was opened.

\section{Design Intent}

The intent of the design in this thesis is to revive the culture of Middle East. And fulfil client needs and provide them with a best possible solution through our ideas and designs. Now these are the original floor

\section{Aims}

a) Al Fahad Historical Neighborhood is very old building, but its interior is very simple.

b) Because of advance architectural building old museum are not much visible

c) So, I will in traduce live caring space and traditional handmade inside the museum.

d) The museum should stand out for the badious inside out.

e) To create more welcoming spaces for the tourist.

f) To introduce badious culture in more advanced way.

g) To unite the inside with the outside, creating interaction of people with museum.

\section{Design process}

Design concept translation: The Arab world is one of the regions that embraces a diverse and rich architectural heritage. However, since the second half of the twentieth century, the vernacular architecture, in the Arab world, was exposed to extensive deterioration and destruction, due to the rapid modernization and drastic economic, social and cultural change that look place in the region. Through history, human civilization has evolved and kept its continuation through integration with the surrounding environment and is dependent on the preservation of nature. Over time and the multifaceted interaction of evolution and human adaptability to the ambient environment, every place and region developed unique characteristic that distinguished it from other places, that is, the core of "identity". Museum is place where we can preserve the identity of original Bedouins and their lifestyle. Museum should speak out for history and timeline of Bedouins. When tourist visit, they have enjoyed and explore the identity and the culture of Arab.

Timber-frame construction: Deployed in both coastal and forest belts, this technique follows a similar procedure to wattle and daub. The vertical wooden posts here tend to have larger bases and have forked ends at its top; narrower beams are the placed on the end and fastened with raffia or bark twine. In between this framework, builders then construct a grid of bamboo members in anticipation of an infill wall treatment of mud daubs or palm mats, depending on building location and function. In coastal communities, palm mats are popular, constructed from fronds of coconut branches woven into a herringbone pattern, using wine and the matts ribbed sections to attach into the framework.

Define culture?: Culture encompasses religion, food, what we wear, how we wear it, our language, marriage, music, what we believe is right or wrong, how we sit at the table, how we greet visitors, how we behave with loved ones, and a million other things,"

Design concept translation?: To revive Arab design, I will use vernacular material to enhance their culture with modern world I will use wood, Adobe and Using old materials that Arab used for their building, earth bricks, soil bricks, adobe, sun dried bricks, clay brick, stabilized bricks, rammed earth or cob. Shape of this building is Small box and square each room is defined. My concept is to make Arabic tradition more appealing to this modern world.

\section{Conclusion}

In this project I will learn vernacular architecture in Arab world. They are many architects who worked on adobe, or vernacular material to improve the living style of many people. One of well know architect Hassan Fathy devoted himself to housing the poor in developing nations and deserves study by anyone involved in rural improvement. Fathy worked to create an indigenous environment at a minimal cost, and in so doing to improve the economy and the standard of living in rural areas. Fathy utilized ancient design methods and materials.

\section{Access \& approach}

Arched arcade: pointed arch and rectangular arch Decorations on the wooden doors, floor and geometric motifs Crenulations along roofline loggia surrounded the courtyard. Most rooms via veranda open in to a central courtyard, so family would spend most of the time in and around the courtyard, house hold utensils were kept in niches set into the wall. veranda or lawn faced the courtyard were a popular space to sit and talk. Majlis for both men and women showing the social interaction between family and visitors. 


\section{Circulation}

The house served as collecting point for fees levied to dhows entering the city the men for receiving and entertaining guest most often used the majlis (Arab seating sofa) And the side entrance is for women who entertaining in their majlis near the entrance There's a summer majlis period on the roof of the house that overlooks the creeks and the building central courtyard. Benches are scattered around the royal grounds for visitors to sit and absorb their surroundings. There's a summer Majlis perched on the roof of the house that overlooks the creek and the building 's central courtyard. Benches are scattered.

\section{Program}

Through my design I have reprogramed sheikh Saeed Al Maktoum museum. The reason to reprogram this museum is to make the building more active. increase the activity and make the building and the heritage alive. Establish regular maintenance and through it the reparation will be done if it is necessary. Management in terms of cleaning and housekeeping. To make the building serviceable air-conditioning, lighting, water and drainage were incorporated.

\section{Conclusions}

The traditional wisdom of how to solve architectural problems due to climate lying beneath the various architectural elements was to be unearthed through this research. The paper establishes that the traditional buildings of the hot-dry climate of the Middle East were and are still, able to function as very good examples of sustainable architecture, in terms of passive cooling. The study shows that the hygrothermal performance in these mud buildings is very good, both in summer and in winter. It points out the various environmental strategies, materials and methods of construction of these buildings in question. Not much has been done in the research of this topic and hence this research is one of the few pioneering researches in Saudi Arabia. It is thus an important step towards rediscovering the traditional architecture of the Middle East from a new angle, the environmental point of view. Modern buildings of these countries are highly dependent on-air conditioning that consumes massive amounts of electricity, and nearly $80 \%$ of household electricity is used for air conditioning [6]. The traditional strategies could easily be adopted for newer buildings that will help cool passively and thus save energy. The many towns that were sculpted with mud architecture in these places were, and some still are, in a ruined state. The respective governments are now restoring these. These examples of sustainable architecture will thus be sources for academic researches, professional inspiration as well as tourism, for years to come.

\section{References}

1. Bekleyen A, N Dalkiliç (2011) The influence of climate and privacy on indigenous courtyard houses in Diyarbakir. Scientific Research and Essays Journal 6(4).

2. Laffah M (2006) The courtyard garden in the Traditional Arab House. In: B Edwards, M Sibley, M Hakmi, P Land (Eds.), Courtyard Housing: Past, Present and Future. Taylor and Francis, New York, USA.

3. Al Awadhi A, Hasan M (2011) Comfort Assessment of a Fully/Semienclosed Courtyard: Case Study of Bahrain Low Rise Villa Housing Model.

4. Souq Waqif (2013) From Survival to Revival.

5. Dammam Al-Eidi L, Vincent P (2008) Saudi Arabia: an environmental overview. Taylor \& Francis, London.

6. Taleb HM, Sharples S (2011) Developing sustainable residential buildings in Saudi Arabia: A case study.

Applied Energy Journal 88.

7. Batterjee SA (2010) Performance of shading device inspired by traditional hejazi houses in Jeddah Saudi Arabia.

8. Ragette F (2012) Traditional Domestic Architecture of the Arab Region. UAE. American University of Sharjah.

9. $30^{\text {th }}$ International Plea Conference 16-18 December 2014, CEPT University, Ahmedabad, India.

\begin{tabular}{l} 
Your next submission with Juniper Publishers \\
will reach you the below assets \\
- Quality Editorial service \\
- Swift Peer Review \\
- Reprints availability \\
- E-prints Service \\
- Manuscript Podcast for convenient understanding \\
- Global attainment for your research \\
- Manuscript accessibility in different formats \\
( Pdf, E-pub, Full Text, Audio) \\
- Unceasing customer service \\
Track the below URL for one-step submission \\
https://juniperpublishers.com/online-submission.php \\
\hline
\end{tabular}

